ORIGINAL ARTICLE

\title{
Clonal B cell populations in a minority of patients with Hashimoto's thyroiditis
}

\author{
A Saxena, E C Alport, O Moshynska, R Kanthan, M A Boctor
}

J Clin Pathol 2004;57:1258-1263. doi: 10.1136/jcp.2004.018416

See end of article for authors' affiliations

.....................

Correspondence to: Dr A Saxena, Department of Pathology, c/o Royal University Hospital, 103 Hospital Drive, Saskatoon, SK S7N 0W8, Canada;

Saxena@sask.usask.ca

Accepted for publication 6 May 2004
Background: Hashimoto's thyroiditis (HT) is a risk factor for thyroid lymphoma, and clonal B cell populations in HT support this link. The literature on B cell clonality in $\mathrm{HT}$ is controversial.

Aims: To identify clonal B cell populations in $\mathrm{HT}$ and to assess their usefulness in differentiating $\mathrm{HT}$ from mucosa associated lymphoid tissue (MALT) lymphoma and predicting future development of lymphoma. Methods: DNA from formalin fixed, paraffin wax embedded blocks of thyroid specimens from 10 patients with HT and two thyroid MALT lymphomas was analysed for B cell clonality by seminested polymerase chain reaction (PCR) using FRIII/LH and FRIII/VDH primers to amplify the IgH gene VDJ region. In one case, PCR products were sequenced. Immunohistochemistry was performed by labelled streptavidin-biotin technique using antibodies to: CD45, CD45RO, CD3, CD20, and cytokeratin.

Results: The histopathological and clinical findings were characteristic of HT. Clonal bands were seen in three and a polyclonal smear pattern was seen in seven cases. The clonal bands in HT were associated with a background smear, and could not be reproduced from other blocks from the same case or from deeper sections of the same block. The clonal bands in thyroid lymphomas were not associated with a background smear and were reproducible. None of the patients with clonal B cells has developed malignant lymphoma during a follow up of 10-13 years.

Conclusions: B cell clonal bands in HT have different features from those in lymphoma (non-pure and nonreproducible) and do not predict future development of lymphoma.

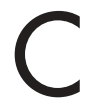
lonal B cell populations have been seen in lymphoid hyperplasia of acquired mucosa associated lymphoid $\checkmark$ tissue (MALT) at different sites including the stomach, ${ }^{12}$ salivary glands, ${ }^{34}$ skin, $^{56}$ ocular adnexa, ${ }^{7}$ and breast. ${ }^{7}$ Although MALT lymphomas develop from acquired MALT, ${ }^{8}$ the B cell clonal populations in hyperplasia of acquired MALT are not always malignant. ${ }^{1-7}$ Furthermore, these clonal populations do not necessarily evolve into malignant lymphoma. ${ }^{1-7}$

Primary MALT lymphomas of the thyroid almost invariably develop from pre-existing Hashimoto's thyroiditis (HT) (relative risk, 67). ${ }^{9}$ Although not a mucosal site, the lymphoid tissue in HT has many features of MALT and shows more pronounced plasma cell differentiation. ${ }^{10}$ The histological features of HT show considerable overlap with MALT lymphoma in the thyroid. ${ }^{10}{ }^{11}$ Although B cell clonality has been demonstrated in $\mathrm{HT}^{7}{ }^{12}$ this finding was not confirmed in subsequent studies. ${ }^{1013} 14$

\section{"Primary mucosa associated lymphoid tissue lymphomas of the thyroid almost invariably develop from pre-existing Hashimoto's thyroiditis"}

The aims of our study were to determine the presence of clonal B cell populations in HT, to ascertain the importance of clonality in distinguishing HT from MALT lymphoma, and to evaluate its role in predicting the subsequent development of lymphoma. We have found that a minority of HT specimens (with no morphological evidence of low grade MALT lymphoma in multiple sections) contain monoclonal B cells. The presence of this clonal population does not equate to malignancy, and is not a reliable marker for predicting the future development of lymphoma.

\section{MATERIAL AND METHODS}

\section{Thyroid specimens}

Formalin fixed, paraffin wax embedded material was taken from 10 consecutive cases ( six from the pathology archives of the Royal University Hospital, University of Saskatchewan and four from the Regina Quapelle Health Region, Canada). All patients had a clinical diagnosis of and histopathological features characteristic of HT. Multiple sections (minimum, eight; range, eight to 14) were evaluated for morphological evidence of low grade MALT lymphoma; none had histological features of low grade MALT lymphoma. ${ }^{1011}$ Lymphoepithelial lesions were defined as clusters of three or more lymphocytes in the glandular epithelium. In addition, the following control specimens were evaluated for clonal B cell populations: low grade MALT lymphoma of the thyroid $(\mathrm{n}=2)$; unremarkable thyroid, obtained at necropsy $(\mathrm{n}=3)$; and thyroid lesions associated with a lymphoid infiltrate: thyrotoxicosis $(n=2)$ and non-specific lymphocytic thyroiditis $(\mathrm{n}=3)$.

\section{Patient chart review}

Patient files at the medical records department were reviewed for clinical presentation, laboratory findings, management, and follow up information. The registration database of the Saskatchewan Cancer Registry, where all the patients from Saskatchewan (the population base of our study) with a diagnosis of any malignancy are registered, was reviewed specifically for the development of thyroid lymphoma. Abbreviations: HT, Hashimoto's thyroiditis; MALT, mucosa associated
lymphoid tissue; PCR, polymerase chain reaction 
Table 1 Clinical features of patients with Hashimoto's thyroiditis and B cell clonality by PCR

\begin{tabular}{|c|c|c|c|c|c|}
\hline No & Age/Sex & Presentation & $\begin{array}{l}\text { Thyroid status at } \\
\text { presentation }\end{array}$ & Clonality & Follow up (years); status \\
\hline 1 & $62 / F$ & Goitre (2 m) & Hypothyroid & Clonal & 13; alive, no lymphoma \\
\hline 2 & $55 / \mathrm{F}$ & Goitre (2 m) & Euthyroid & Clonal & 11 ; alive, no lymphoma \\
\hline 3 & $55 / \mathrm{F}$ & Goitre (1 m) & Euthyroid & Clonal & 10; alive, no lymphoma \\
\hline 4 & $69 / \mathrm{F}$ & Goitre (1 m) & Hypothyroid & Polyclonal & 1 ; died, unrelated cause \\
\hline 5 & $57 / F$ & Goitre (2 y) & Euthyroid & Polyclonal & 11; alive, no lymphoma \\
\hline 6 & $61 / F$ & Goitre (2 m) & Euthyroid & Polyclonal & 13; alive, no lymphoma \\
\hline 7 & $59 / \mathrm{F}$ & Goitre (5 m) & Hypothyroid & Polyclonal & 13; alive, no lymphoma \\
\hline 8 & $60 / F$ & Goitre (2 m) & Hypothyroid & Polyclonal & 11; alive, no lymphoma \\
\hline 9 & $39 / F$ & Goitre (2 m) & Euthyroid & Polyclonal & 11; alive, no lymphoma \\
\hline 10 & $64 / \mathrm{F}$ & Goitre $(2 \mathrm{~m})$ & Euthyroid & Polyclonal & 8; alive, no lymphoma \\
\hline
\end{tabular}

\section{Immunohistochemistry}

The labelled streptavidin-avidin technique ${ }^{16}$ was used to localise the primary antibodies after microwave antigen retrieval. The primary monoclonal antibodies used in our study were directed at: CD45, CD45RO, CD3, CD20, $\kappa$ chain, $\lambda$ chain, CD21, CD35, and cytokeratin.

\section{Immunoglobulin gene rearrangement by PCR}

DNA was extracted from $5 \mu \mathrm{m}$ sections using the QIAamp tissue kit (Qiagen, Hilden, Germany) and the amount of DNA was adjusted to $500 \mathrm{ng} / \mu \mathrm{l}$. A modified seminested protocol was used for amplification of the VDJ region of the immunoglobulin heavy chain gene $(\operatorname{IgH}) \cdot{ }^{17-19}$ Two rounds of PCR were performed, the first with the FRIII $\left(5^{\prime}-\right.$ ACACGGC $\left.[\mathrm{C} / \mathrm{T}][\mathrm{G} / \mathrm{C}] \mathrm{TGTATTACTGT}-3^{\prime}\right)$ and LJH $\left(5^{\prime}-\right.$ TGAGGAGACGGTGACC-3') primers, and the second with the FRIII and VLJH (5'-GTGACCAGGGTNCCTTGGCCCCAG$\left.3^{\prime}\right)$ primers. ${ }^{20}{ }^{21}$ The total volume of the reaction mixture was $25 \mu \mathrm{l}$; it contained $500 \mathrm{ng}$ of template DNA (in $1 \mu \mathrm{l}$ ); $2.0 \mu \mathrm{l}$ of dNTP mix (working concentration, 10mM of each dNTP; Gibco BRL Life Technologies, Burlington, Ontario, Canada); $0.5 \mu \mathrm{l}$ of each primer (working concentration, $2 \mathrm{pM} / \mu \mathrm{l}$; Gibco BRL Life Technologies); $1.5 \mu$ l of Red-Taq DNA polymerase ( 1 unit/ $\mu \mathrm{l}$; Sigma, St Louis, Missouri, USA); $2.5 \mu \mathrm{l}$ of $10 \times$ Red Taq PCR reaction buffer (Sigma), containing 100mM Tris/ HCL (pH 8.3), 500mM KCL, $11 \mathrm{mM} \mathrm{MgCl}_{2}$, and $0.1 \%$ gelatin; $2.5 \mu \mathrm{l}$ of $50 \mathrm{mM} \mathrm{MgCl}_{2}$; and PCR water (VWR Canlab, Mississauga, Ontario, Canada) to a final volume of $25 \mu \mathrm{l}$. Aliquots $(1 \mu \mathrm{l})$ of the first round PCR product were amplified in the second round PCR. Amplification (first round, 25 cycles; second round, 20 cycles) was carried out in a PTC-200

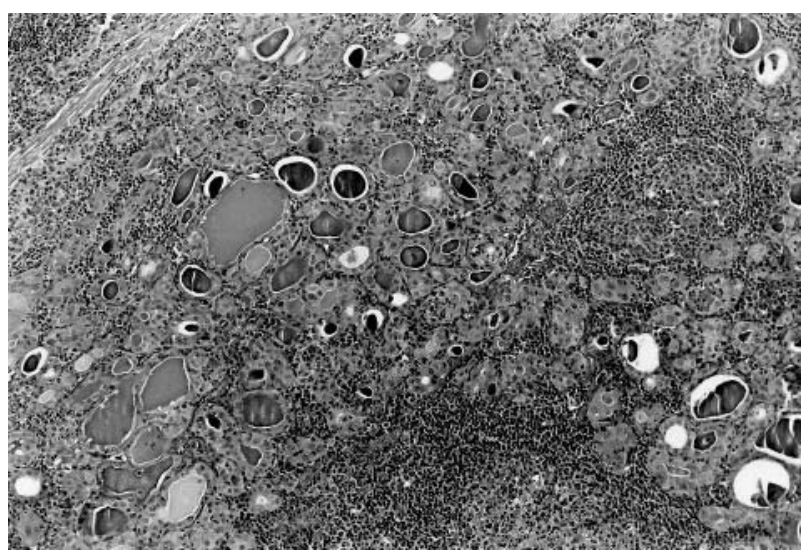

Figure 1 Interfollicular lymphoid infiltrate and Hurthle cell change in thyroid acini. Haematoxylin and eosin stain; original magnification, $\times 70$.
DNA engine thermocycler (MJ Research Inc, Watertown, Massachusetts, USA) as follows: pre-PCR segment, initial denaturation (five minutes at $95^{\circ} \mathrm{C}$, one cycle), PCR segment (denaturation for one minute at $94^{\circ} \mathrm{C}$, annealing for one minute at $50^{\circ} \mathrm{C}$, and extension for one minute at $72^{\circ} \mathrm{C}$ ), and a post-PCR segment, final extension ( 10 minutes at $72^{\circ} \mathrm{C}$ ). Each amplification was duplicated and a $5 \mu \mathrm{l}$ aliquot of the PCR products was electrophoresed for 75 minutes at $165 \mathrm{~V}$ on $10 \%$ polyacrylamide gels (acrylamide/bisacrylamide content of 29/1); this can resolve three nucleotide base pair differences. ${ }^{22}$ The presence of clonal bands of different sizes (base pairs) was taken as evidence of bands of different sequences. The products were visualised under ultraviolet light after staining with ethidium bromide on a gel documentation system (Gel-Doc 2000; BioRad, Mississauga, Ontario, Canada), and the exact size was determined using the software program (Quantity One, BioRad).

Clonality was established by the presence of one or two discrete bands in the $80-140$ bp region, ${ }^{17}$ and polyclonality by a diffuse smear pattern or multiple faint indistinct bands. ${ }^{22}$ All tests were run in duplicate. To assess the reproducibility of clonal bands, DNA was amplified from different areas of the lesion, sections from a deeper level, or sections from another block. The deeper sections represented levels 18-20 (90$100 \mu \mathrm{m}$ deeper, each section being $5 \mu \mathrm{m}$ thick). The next adjacent $5 \mu \mathrm{m}$ section was examined for histological features, specifically, the presence of lymphoid follicles. Standard controls were run with each batch of PCR, these included: reagent control (no template DNA), negative tissue control (sample with no IgH gene rearrangement), and positive tissue control (known lymphoma case previously shown to

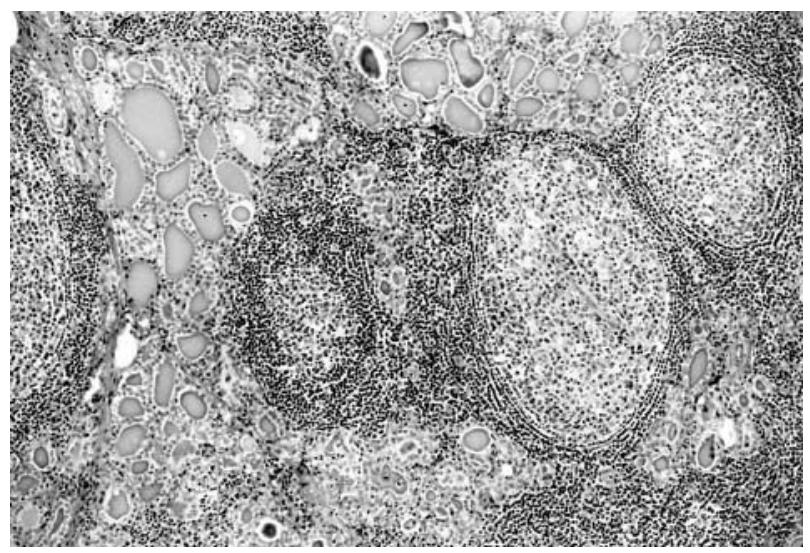

Figure 2 Numerous lymphoid follicles with a germinal centre and mantle zone and interfollicular lymphoid infiltrate in Hashimoto's thyroiditis. Haematoxylin and eosin stain; original magnification, $x 70$. 
have a clonal band by PCR). Amplification of $\beta$ actin was used as evidence of amplifiable DNA from all samples. Sequencing of PCR products was performed in one case (case 3).

\section{RESULTS}

\section{Clinical features}

Table 1 summarises the clinical features of the patients. All patients were women with an age range of 39 to 69 years (mean, 54). In all patients, the disease presented as a goitre of variable duration (one month to two years). At presentation, six patients were euthyroid and four were hypothyroid. Partial thyroidectomy was performed in all patients. Nine patients have remained well, whereas one died after one year as a result of an unrelated cause. Review of the patient files showed no evidence of recurrent thyroid enlargement, systemic lymphadenopathy, organomegaly, or leucocytosis. None of the patients has developed lymphoma during the clinical follow up (range, eight to 13 years), including three patients with a clonal B cell population (follow up, 10-13 years).

\section{Histopathological and immunohistochemical findings}

All patients had classic features of HT. An extensive lymphoid infiltrate was associated with acinar atrophy and Hurthle cell metaplasia (fig 1), and in four cases with fibrosis and lobulation. The lymphoid infiltrate was arranged as lymphoid follicles and interfollicular small lymphocytes (fig 2), plasma cells, scattered lymphoplasmacytoid cells, and a few large transformed cells. Most lymphoid follicles had a well defined germinal centre and mantle zone; however, a marginal zone was not present. In five cases, plasma cells were prominent in the interfollicular region (results not shown), and four of these showed prominent fibrosis and lobulation. Histological features of low grade MALT lymphoma were not present. Specifically, effacement of thyroid acini and follicular colonisation were absent. The interfollicular area was not greatly expanded and sheets or aggregates of centrocyte-like cells, small lymphocytes, or lymphoplasmacytoid cells were not present.

Most of the lymphoid infiltrate in HT arranged as lymphoid follicles was composed of B cells (CD45+, CD20+, CD45RO-, CD3-). The interfollicular lymphoid infiltrate was composed predominantly of $\mathrm{T}$ cells (CD45RO+, CD3+, CD20-) admixed with a very small number of $\mathrm{B}$ cells and plasma cells. The $\mathrm{B}$ cells and plasma cells were not light chain restricted.

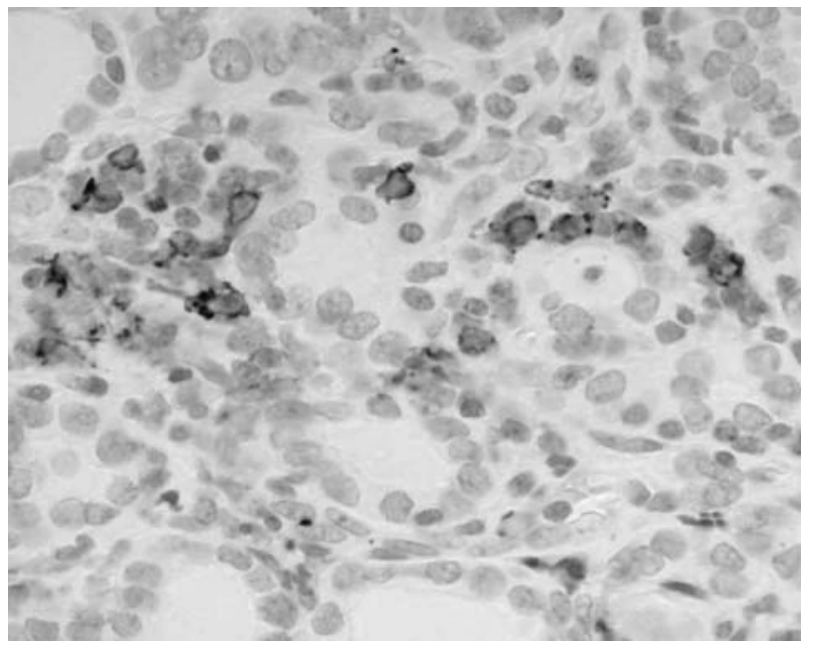

Figure 3 Intraepithelial CD20+ B cells and a small lymphoepithelial lesion. Immunoperoxidase; original magnification, $\times \mathbf{4 2 0}$.

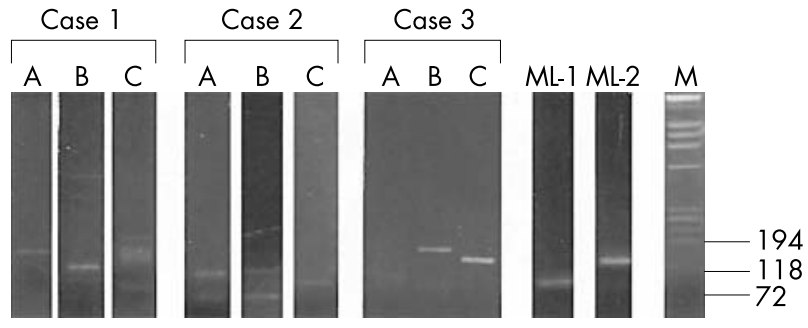

Figure 4 Ethidium bromide stained 10\% polyacrylamide gel of seminested polymerase chain reaction products (FRIII/LH and FRIII/ VUH primers) from DNA samples as follows: first nine lanes, nonreproducible bands in Hashimoto's thyroiditis - three separate blocks from cases 1, 2, and 3; lanes ML-1 and ML-2, pure clonal bands from two cases of thyroid mucosa associated lymphoid tissue lymphoma (these bands were reproducible - results not shown); $M$, molecular weight markers (size in base pairs).

Scattered intraepithelial B cells were present in all cases, and occasional B cell lymphoepithelial lesions were seen in five cases (fig 3). T cell non-destructive lymphoepithelial lesions were present in most (eight of 10) cases.

\section{Molecular findings (figs 4 and 5 )}

Amplifiable DNA was obtained from all cases. In HT, a distinct clonal band in the appropriate region (80-160 bp) superimposed on a smear was seen in three cases, and a diffuse smear pattern (polyclonal) was seen in seven cases. Both cases of low grade MALT lymphoma had a single distinct band. In non-specific lymphocytic thyroiditis and thyrotoxicosis a diffuse smear was seen, but PCR products were not detected in DNA from unremarkable thyroid.

\section{Reproducibility of bands}

The bands were reproducible in two cases of low grade MALT lymphoma (results not shown) from deeper sections of the

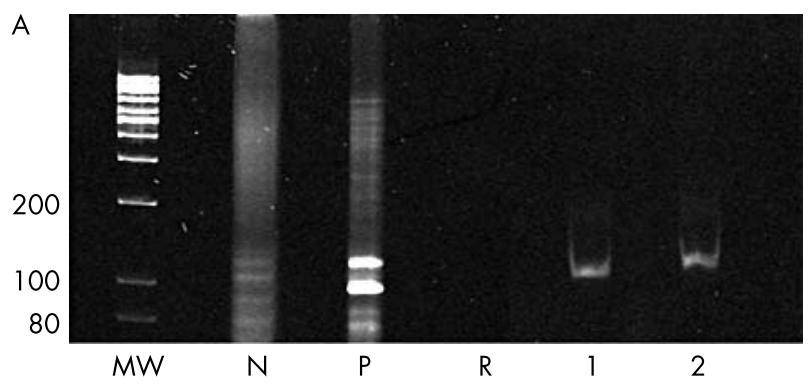

$\mathrm{VH6}-$ CTGTCGACACGGCTCTGTATTACTGTGCAGGCAGAGGGTTACTGTGGTTCA GGGAGTCCGAACTGGTTCGACCCCTGGGGCCAGGGAACCCTGGTCACCG TCTCCTCAGGT $\mathrm{JH} 5 \mathrm{~b}$

$\mathrm{VH} 6-1$ Random nucleotides CTGTCGACACGGCTCTGTATTACTGTGCGATGGGAGATTGTGCTACTATCA CCTATTGTGCGGGATTTTTCCACCACTGGGGCCAGGGCACCCTGGTCACC GTCTCCTCAGGT $\mathrm{JH} 1$

Figure 5 (A) Ethidium bromide stained 10\% polyacrylamide gel of polymerase chain reaction products (VH and $\mathrm{JH}$ primers) from DNA samples as follows: MW, molecular weight markers (size in base pairs); $P$, positive control; $N$, negative control; $R$, reagent control (no DNA); lanes 1 and 2, two distinct clonal bands from the same paraffin wax block of Hashimoto's thyroiditis from two sections $25 \mu \mathrm{m}$ apart. (B) The clonal bands in lanes 1 and 2 have different rearranged VDJ region sequences of the immunoglobulin heavy chain gene (lgH) (top from lane 1 and bottom from lane 2). 
same paraffin wax block and from other paraffin wax blocks. The clonal bands seen in three cases of HT were not reproducible when PCR was performed on the DNA extracted from deeper sections of the same paraffin wax block or from other blocks of the same case.

In one of three cases (case 2), a clonal band was seen in at least one-either superficial or a deeper section of the same paraffin wax block. In two of three cases (cases 1 and 3), clonal bands were present in both the superficial and the deeper sections, but these were of different size. In one of these cases (case 3), not only was the size of the bands different (fig 5A), but the sequences were also different (fig 5B). In all cases with a clonal band from one paraffin wax block, the DNA from the other blocks was either polyclonal or produced a clonal band of different size. In all cases, DNA obtained from one of the three blocks was polyclonal (fig 4; case 1, lane C; case 2, lane B; and case 3, lane A). All findings (bands or smears) were confirmed by running the samples in duplicate.

Association with a background polyclonal smear In all three cases, the clonal bands were "impure", and were associated with a background polyclonal smear in at least one level from a paraffin wax block.

\section{DISCUSSION}

In our study, we describe the presence of clonal B cell populations in a minority (three of 10) of HT thyroid specimens that had no histological evidence of malignant lymphoma. The clonal bands were often seen against the background of a polyclonal smear and were not reproducible when deeper sections or other tissue blocks were used. None of the histopathological features correlated with B cell clonality. These clonal populations have not been associated with the subsequent development of lymphoma after a long clinical follow up (10-13 years).

A few studies (table 2) have analysed B cell clonality in HT and clonal B cell populations were not uniformly detected. ${ }^{7} 10^{12-14}$ 23-25 These discrepancies could be the result of any of the following reasons, in addition to sampling error. The sensitivity of Southern blot analysis, usually $2-5 \%,{ }^{17}$ is low compared with PCR ( $1 / 10^{3}$ cells $),{ }^{18}$ and could account for negative results in the study of Ben-Ezra et al, ${ }^{13}$ although Knowles and colleagues ${ }^{7}$ were able to detect a clonal population using this technique. The immunophenotypic criteria for monoclonality ${ }^{20}$ adopted by Matsuyabashi ${ }^{12}(\kappa: \lambda$ ratio $>3: 1$ or $\lambda: \kappa$ ratio $<2: 1$ ) have been revised in favour of a much greater predominance of one light chain (light chains ratio $\geqslant 10: 1),{ }^{26}$ and the true incidence of clonality in their study was probably lower. The differences between our study and that reported by Hsi and colleagues ${ }^{14}$ could result from the selection of cases or the stage in the natural history of the disease, or might be related to the duration of the disease before thyroidectomy was performed. Hyjek and Isaacson ${ }^{10}$ used monoclonality as evidence of lymphoma; however, the five cases of HT reclassified as lymphoma had histological features of low grade MALT lymphoma. It is also possible that the high incidence of clonality reported by Tiemann et al may have included cases with lymphoma from the outset because 26 of 40 patients developed lymphoma in their series. ${ }^{25}$

In our study, B cell monoclonal populations were not found in "normal" thyroid, thyrotoxicosis, or non-specific lymphocytic thyroiditis. Two cases of low grade MALT lymphoma had pure clonal bands with no background smearing and were reproducible. The clonal populations in HT were associated with a background smear and were not "pure". Similar findings of clonal bands against a polyclonal smear pattern have been observed in both reactive lymphoid infiltrates and some examples of malignant lymphoma, ${ }^{2} 1927$ and reflect the background non-neoplastic B cell population. Although a pure band is considered diagnostic of lymphoma, ${ }^{28}$ a dominant band associated with a polyclonal smear should be interpreted cautiously in conjunction with the histopathological findings.

The clonal bands in HT were not reproducible. Of the two possible reasons for this lack of reproducibility-a low quantity of $\mathrm{DNA}^{1929}$ or a paucity of $\mathrm{B}$ cell clones ${ }^{2}{ }^{30}{ }^{31}$ - the first is unlikely because all cases of HT had florid lymphoid hyperplasia and yielded a large amount of amplifiable DNA. The second reason is more likely, and might represent selective proliferation of a small number of B cell clones as part of the autoimmune response in HT, or primer dependent preferential amplification. The observation that the CD8+ component of the $\mathrm{T}$ cell immune response in HT uses a restricted $V \alpha$ repertoire supports the oligoclonal nature of the immune response in autoimmune diseases. ${ }^{32}$ In a manner similar to lymphoid infiltrates in the stomach, ${ }^{33}$ the lesions of HT may have a small number of scattered unique clones giving rise to bands of different sizes from different parts of the specimen. Alternatively, only a focal area may be involved, with a dominant clone producing a unique clonal band, which cannot be reproduced from other areas. The existence of a small number of clones is also supported by the demonstration of: (1) clonal populations in another autoimmune setting (salivary glands in Sjogren's syndrome) ${ }^{3} 434$ and (2) non-reproducible bands in reactive and tumour follicles from B cell lymphoma. ${ }^{21}$

"In a manner similar to lymphoid infiltrates in the stomach, the lesions of Hashimoto's thyroditis may have a small number of scattered unique clones giving rise to bands of different sizes from different parts of the specimen"

Table 2 Studies assessing B cell clonality in Hashimoto's thyroiditis

\begin{tabular}{lllll}
\hline First author & Technique & No. of cases & Clonality & Year/Ref \\
\hline Ben-Ezra & SBH & 4 & No & $1988 / 13$ \\
Knowles & SBH & 1 & Yes (1/1) & $1989 / 7$ \\
Katzin & SBH & 6 & No & $1989 / 23$ \\
Hyjek & IHC & 21 & Yes* $(5 / 21)$ & $1988 / 10$ \\
Matsubayashi & Flow cytometry and IHC & 5 & Yes (5/5) & $1990 / 12$ \\
Wacker & PCR (TGGE) & 18 & Yes (4/18) & $1994 / 24$ \\
Tiemann & PCR (TGGE) & 40 & Yes (8/40) & $1996 / 25$ \\
Hsi & PCR and IHC & 40 & No & $1998 / 14$ \\
Present study & PCR and sequencing & 10 & Yes (3/10) & \\
\hline
\end{tabular}

*Initially diagnosed as Hashimoto's thyroiditis but revised to malignant lymphoma in view of clonal population. However, the histology of low grade mucosa associate lymphoid tissue lymphoma was noticed in these cases. IHC, immunohistochemistry; PCR, polymerase chain reaction; SBH, Southern blot hybridisation; TGGE, temperature gradient gel electrophoresis. 


\section{Take home messages}

- B cell clonal bands in Hashimoto's thyroiditis (HT) have different features from those in lymphoma-they are impure and not reproducible

- These clonal bands do not predict the future development of lymphoma

- The histological features of HT and low grade mucosa associated lymphoid tissue lymphoma often overlap, but the demonstration of $B$ cell clonality by polymerase chain reaction is not sufficient by itself to diagnose lymphoma

HT is an established risk factor for the development of lymphoma in the thyroid. ${ }^{9}$ The presence of clonal B cells would support this link; alternatively, these clonal B cells may represent a stage in the natural history of the disease, and do not necessarily mean progression to overt lymphoma. None of the patients with HT, including three with clonal B cell populations, has developed lymphoma (follow up interval, 10-13 years). A similar scenario has been seen at other acquired MALT sites-stomach, ${ }^{1}{ }^{2}$ salivary glands, ${ }^{3} 4734$ skin, ${ }^{5635}$ ocular adnexa, ${ }^{76}$ and breast ${ }^{7}$ - where clonal B cells have not always progressed to frank lymphoma even after a long clinical follow up..$^{57} 378$ Sometimes, histological regression and the disappearance of these clonal populations has occurred after treatment that reduces or eliminates the offending antigen. ${ }^{139}{ }^{40}$ In addition, the monoclonal cells may not proliferate in the absence of $\mathrm{T}$ cell help, ${ }^{41}$ or may differentiate into terminal non-dividing cells and undergo senescence. ${ }^{42}$

Clonality is not considered synonymous with malignancy, and the concept of "multistep transformation" ${ }^{43}$ has been extended to lymphoid lesions, ${ }^{7128}$ with the proposal of "monoclonal lymphoproliferative disease of undetermined significance" 44 and "clonal disorder of uncertain malignant potential" 28 for those lesions that are clonal but not overtly malignant. The development of lymphoma would require additional genetic events. ${ }^{28}$ In the absence of multiple lesions or masses, or characteristic histopathological features, the demonstration of clonality should not be taken as evidence of lymphoma. ${ }^{428}$

Because the histological features of HT and low grade MALT lymphoma often overlap, the distinction may require immunophenotyping and molecular genetic analysis. Our study has shown that the demonstration of B cell clonality by PCR is not sufficient by itself to diagnose lymphoma. This becomes even more important when interpreting fine needle aspiration cytology, which is often an initial step in evaluating thyroid lesions. In the absence of classic features of HT or lymphoma, relying on molecular evidence of clonality to diagnose lymphoma may lead to erroneous interpretation, and the pathologists should be aware of this pitfall. However, in the absence of well defined histological features of MALT lymphoma in surgical pathology specimens (lobectomy, thyroidectomy), this test should be repeated using additional blocks to confirm the reproducibility of the clonal bands. Furthermore, the clonal populations are not necessarily associated with progression to lymphoma.

\section{ACKNOWLEDGMENTS}

We thank Mr R Cordeiro, Division of Molecular Pathology, Department of Laboratory Medicine, Saskatoon Health Region for technical assistance.

\section{Authors' affiliations}

A Saxena, O Moshynska, R Kanthan, Department of Pathology, Royal University Hospital, Saskatoon, Saskatchewan S7N 0W8, Canada E C Alport, Department of Laboratory Medicine, Regina Qu'apelle Health Region, Saskatchewan S4T 1A5, Canada

M A Boctor, Internal Medicine (Division of Endocrinology), Royal University Hospital, University of Saskatchewan, Saskatchewan, Canada

\section{REFERENCES}

1 Wotherspoon AC, Doglioni C, Diss TC, et al. Regression of primary low grade B-cell gastric lymphoma of mucosa-associated lymphoid tissue type after eradication or Helicobacter pylori. Lancet 1993;342:575-8.

2 Torlakovic E, Cherwitz DL, Jessurun J, et al. B-cell rearrangement in benign and malignant lymphoid proliferations of mucosa-associated lymphoid tissue and lymph nodes. Hum Pathol 1997;28:166-73.

3 Fishleder A, Tubbs R, Hesse B, et al. Uniform detection of immunoglobulingene rearrangement in benign lymphoepithelial lesions. N Engl J Med 1987;316:1118-21

4 Quintana PG, Kapadia SB, Bahler DW, et al. Salivary gland lymphoid infiltrates associated with lymphoepithelial lesions: a clinicopathologic, immunophenotypic, and genotypic study. Hum Pathol 1997;28:850-61

5 Wood GS, Ngan B-Y, Tung R, et al. Clonal rearrangements of immunoglobulin genes and progression to B-cell lymphoma in cutaneous lymphoid hyperplasia. Am J Pathol 1989;135:13-19.

6 Wechsler J, Bagot M, Henni T, et al. Gene analysis in 18 cases of cutaneous lymphoid infiltrates of uncertain significance. Arch Pathol Lab Med 1995; 119:157-62.

7 Knowles DM, Athan E, Ubriaco A, et al. Extranodal noncutaneous lymphoid hyperplasia represents a continuous spectrum of B-cell neoplasia: demonstration by molecular genetic analysis. Blood 1989;73:1635-45.

8 Isaacson PG. The MALT lymphoma concept updated. Ann Oncol 1995;6:319-20.

9 Holm L-E, Blomgren H, Lowhagen T. Cancer risks in patients with chronic lymphocytic thyroiditis. N Engl J Med 1985;312:601-4.

10 Hyjek E, Isaacson PG. Primary B-cell lymphoma of the thyroid and its relationship to Hashimoto's thyroiditis. Hum Pathol 1988;19:1315-26.

11 Isaacson PG. Lymphoma of the thyroid gland. In: Schmid KW, Bocker W, eds. Current topics in pathology, Vol. 91. Berlin: Springer Verlag, 1997:1-14

12 Matsuyabashi S, Tamai H, Morita T, et al. Hashimoto's thyroiditis manifesting monoclonal lymphocytic infiltration. Clin Exp Immunol 1990;79:170-4.

13 Ben-Ezra J, Wu A, Sheibani K. Hashimoto's thyroiditis lacks detectable clonal T cell and B cell gene rearrangements. Hum Pathol 1988;19:1444-8.

14 Hsi ED, Singleton TP, Svoboda S, et al. Characterization of the lymphoid infiltrate in Hashimoto's thyroiditis by immunohistochemistry and polymerase chain reaction for immunoglobulin heavy chain gene rearrangement. Am J Clin Pathol 1998; 110:327-33.

15 Isaacson PG, Androulakis-Papachristou A, Diss TC, et al. Follicular colonization in thyroid lymphoma. Am J Pathol 1992;141:43-52.

16 Warnke R, Levy R. Detection of $T$ and $B$ cell antigens with hybridoma monoclonal antibodies. A biotin avidin horseradish peroxidase method. $J$ Histochem Cytochem 1980;28:771-4.

17 Diss TC, Peng H, Wotherspoon AC, et al. Detection of monoclonality in low grade B-cell lymphomas using the polymerase chain reaction is dependent on primer selection and lymphoma type. J Pathol 1993;169:291-5.

18 Ramasamy I, Brisco M, Morley AA. Improved PCR method for detecting monoclonal immunoglobulin heavy chain rearrangement in B-cell neoplasms. J Clin Pathol 1992;45:770-5.

19 Wan JH, Sykes PJ, Orell SR, et al. Rapid method for detecting monoclonality in $B$ cell lymphoma in lymph node aspirates using the polymerase chain reaction. J Clin Pathol 1992;45:420-3.

20 Sukpanichnant S, Vnencak-Jones CL, McCurley TL. Determination of B-cell clonality in paraffin embedded endoscopic biopsy specimens of abnormal lymphocytic infiltrates and gastrointestinal lymphoma by polymerase chain reaction. Am J Clin Pathol 1994;102:299-305.

21 Pan LX, Diss TC, Peng HZ, et al. Clonality analysis of defined B-cell populations in archival tissue sections using microdissection and the polymerase chain reaction. Histopathology 1994;24:323-7.

22 Reed TJ, Reid A, Wallberg K, et al. Determination of B-cell clonality in paraffin-embedded lymph nodes using the polymerase chain reaction. Diagn Mol Pathol 1993;2:42-9.

23 Katzin WE, Fishleder AJ, Tubbs RR. Investigation of the clonality of lymphocytes in Hashimoto's thyroiditis using immunoglobulin and T-cell receptor gene probes. Clin Immunol Immunopathol 1989;51:264-74.

24 Wacker HH, Tiemann M, Menke MA, et al. Intensification of sensitivity of monoclonality determination of B-cells in autoimmune thyroiditis and low malignancy B-NHL of the MALT type using temperature gradient gel electrophoresis (TGGE) [in German]. Verh Dtsch Ges Pathol 1994;78:208-13

25 Tiemann M, Asbeck R, Wacjer HH. Clonal B-cell reaction in Sjogren's disease and Hashimoto's autoimmune thyroiditis [in German]. Pathologie 1996; 17:289-95

26 Picker LF, Weiss LM, Medeiros JL, et al. Immunophenotypic criteria for the diagnosis of non-Hodgkin's lymphoma. Am J Pathol 1987;59:52-60.

27 McCarthy KP, Sloane JP, Wiedemann IM. Rapid method for distinguishing clonal from polyclonal B cell populations in surgical biopsy specimens. J Clin Pathol 1990;43:429-32. 
28 Collins RD. Is clonality equivalent to malignancy: specifically, is immunoglobulin gene rearrangement diagnostic of malignant lymphoma? Hum Pathol 1997;28:757-9.

29 Taylor JME, Spagnolo DV, Kay PH. B-cell target DNA quality is a critical factor in the interpretation of B-cell clonality by PCR. Pathology 1997:29:309-12.

30 Hsi ED, Grenson JK, Singleton TP, et al. Detection of immunoglobulin heavy chain gene rearrangement by polymerase chain reaction in chronic active gastritis associated with Helicobacter pylori. Hum Pathol 1996;27:290-6.

31 Kossakowska AE, Eyton-Jones S, Urbanski SJ. Immunoglobulin and T-cell receptor gene rearrangements in lesions of mucosa associated lymphoid tissue. Diagn Mol Pathol 1993;2:233-40.

32 Mclntosh RS, Watson PF, Weetman AP. Analysis of the T-cell receptor V repertoire in Hashimoto's thyroiditis: evidence for the restricted accumulation of CD8+ T-cells in the absence of CD4+ T-cell restriction. J Clin Endocrinol Metab 1997:82:1140-6.

33 Ott MM, Linke B, Gerhard N, et al. Characterization of clonal B-cell populations in gastric lymphomas of MALT and related chronic gastritis using the polymerase chain reaction. Verh Dtsch Ges Pathol 1994;78:302-4

34 Freimark B, Fantozzi R, Bone R, et al. Detection of clonally expanded salivary gland lymphocytes in Sjogren's syndromes. Arthritis Rheum 1989;32:859-69.

35 Albrecht S, Hosftadter S, Artsob H, et al. Lymphadenosis benigna cutis resulting from Borrelia infection (Borrelia lymphocytoma). J Am Acad Dermatol 1991;24:621-5.
36 Takano Y, Okudaira M. Molecular-genetic analysis of ocular adnexal benign lymphoid hyperplasias by a two-step polymerase chain reaction. J Cancer Res Clin Oncol 1992;1 18:581-6.

37 Schmid U, Eckert F, Greisser H, et al. Cutaneous follicular lymphoid hyperplasia with monotypic plasma cells. A clinicopathologic study of 18 patients. Am J Surg Pathol 1995;19:12-20.

38 Savio A, Franzin G, Wotherspoon AC, et al. Diagnosis and posttreatment follow up of Helicobacter pylori-positive gastric lymphoma of mucosaassociated lymphoid tissue: histology, polymerase chain reaction or both? Blood 1996:87:1255-60.

39 Garbe C, Stein H, Dienemann D, et al. Borrelia burgdorferi-associated cutaneous B-cell lymphoma: clinical and immunohistological characterization of four cases. J Am Acad Dermatol $1991 ; 24: 584-90$.

40 Bianche GE. Die Penicillinbehandlung der Lymphozytome. Dermatologica 1950;100:270-3.

41 Hussell T, Isaacson PG, Crabtree JE, et al. The response of cells from low grade B-cell gastric lymphomas of mucosa-associated lymphoid tissue to Helicobacter pylori. Lancet 1993;342:571-4.

42 Okazaki K, Morita M, Yamamoto Y. Gene rearrangements, Helicobacter pylori, and gastric MALT lymphoma. Lancet 1993;343:1636.

43 Fearon ER, Vogelstein B. A genetic model of colorectal carcinogenesis. Cell 1990;61:759-67.

44 Ludwig CU, Genick M, Shipman R. Multistep transformation in low grade lymphoproliferative diseases. Ann Oncol 1993;4:825-30.

\section{$\mathrm{ECHO}$}

\section{Dark ground microscopy and treponemal serology for diagnosis of early syphilis}

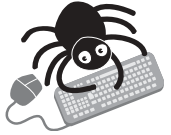

Please visit the Journal of Clinical Pathology website [www. jclinpath.com] tor a link to the full text of this article.
$\mathrm{T}$ here has been a recent increase in the incidence of infectious syphilis in the UK, especially in homosexual men. Dark ground microscopy (DGM) provides immediate diagnosis but requires a dark field microscope and trained staff and, because syphilis has been uncommon in the UK until recently, many genitourinary medicine physicians are unskilled in its use. Other direct detection methods such as direct fluorescent antibody staining (DFA-Tp) or polymerase chain reaction (PCR) are more difficult or slow and serological tests have limited sensitivity for primary syphilis. Workers in London have confirmed the usefulness of DGM.

Their retrospective case note review included 50 patients with primary syphilis (PS) and 36 with secondary syphilis (SS). The diagnosis of PS was based on the presence of ulcers of penis, anus, or outer lip and positive DGM and/or positive serology. SS was diagnosed from clinical signs (lesions of penis, scrotum, vulva, or extragenital skin) and positive serology or DGM. Lymph node aspirates for DGM were not performed. Treponemal enzyme immunoassay (EIA) was done for all patients and positive samples were tested further with rapid plasma reagin (RPR) and TPPA tests. Selected samples were sent for EIA-IgM testing.

DGM was performed in 31 of the 50 cases of PS and was positive in 30 (from lesions on the genitalia (23), anus (5), and lip (2). The test was positive at first visit in 24 patients. The reasons for not doing DGM in 19 patients were:- wrong clinical diagnosis of genital herpes (6), atypical ulcers and syphilis not suspected (7), no trained personnel available (4), DGM microscope not working (1), and inner lip lesion with possibility of contamination with nonsyphilitic treponemes (1). Treponemal EIA-IgM testing was done for 27 cases of PS and was positive in 21, equivocal in four, and negative in two. DGM was performed in three EIAIgM-equivocal cases and one negative and was positive in all four. Treponemal EIA (not IgM-specific) was initially negative in 17 cases of PS (34\%) but DGM was positive in all 13 of these 17 on whom it was performed. EIA-IgM was positive in 12 of 14 EIA-negative cases tested.

All 36 cases of SS had positive treponemal serology on first testing. DGM in 19 cases was positive in 16. The DGM positive lesions were genital (7) and extragenital cutaneous (9). In 15 cases DGM was positive at the first visit. The reasons for not doing DGM in 17 cases were:- wrong diagnosis of rash (9), positive syphilis serology in asymptomatic HIV positive patients (2), no trained personnel (5), and reason not documented (1).

DGM is rapid and sensitive and allows immediate diagnosis, treatment, and partner notification. All genitourinary medicine clinics should have trained staff ready to do DGM.

\ Wheeler H L, et al. Sexually Transmitted Infections 2004;80:41 1-414. 